\title{
Analyzing Renewable Energy Policies - Using the Pay-Off Method to Study the Finnish Auction-Based Renewable Energy Policy
}

\author{
L. Hietanen ${ }^{1}$, M. Kozlova ${ }^{1 *}$, and M. Collan ${ }^{1,2}$ \\ ${ }^{1}$ School of Business and Management, LUT University, Lappeenranta 53850, Finland \\ ${ }^{2}$ VATT Institute for Economic Research, Helsink 00101, Finland
}

Received 11 July 2020; revised 25 August 2020; accepted 01 September 2020; published online 31 December 2020

\begin{abstract}
Design of support-mechanisms is an important component of renewable energy policy. In order to be able to choose desirable designs one must have a good understanding of the most likely outcomes from different policy designs - this calls for proper before-implementation policy analysis and especially for analysis the results of which are intuitively understandable for the decisionmakers. We propose a simple process, based on the fuzzy pay-off method, for the purpose of analyzing renewable energy support designs in the context of auction-based support mechanism implementation. A numerical case from Finland is used to illustrate the proposed process. The results show that the process is relatively simple to use and able to produce intuitively understandable relevant information for design selection.
\end{abstract}

Keywords: fuzzy pay-off method, renewable energy, investment valuation, auctions, Finland

\section{Introduction}

Recent years have carried massive changes in the support policies for renewable energy (RE) used worldwide. The main global trend at the time of writing is cancelling the incumbent feed-in policies for utility-scale investments and introducing auction based policies instead (Murdock et al., 2018, 2019). The number of countries switching to an auction-based mechanism reached a total of fifty in 2018 (Murdock et al., 2019). The primary reason behind this shift is the inability of feed-in policies to effectively adapt to the falling technology costs and the resulting "too high" subsidy levels. The problem and the massive need for change has been partially caused by the use of analysis techniques that have been only poorly able to inform policymakers and investors about the effects of (technology) changes to different RE support policy types and specific policies. The focus of this paper is on the methods used in policy evaluation and on the effect of the policies on RE investment profitability (and thus indirectly the desirability of investing in RE within a given policy).

We propose the use of a simple analysis process for the evaluation of the effect of RE policies on RE investments, based on using the fuzzy pay-off method (FPOM) (Collan et al., 2009). The method used is a recently introduced robust and simple profitability analysis method. Its characteristics spellout ease-of-use and speed - things that make the method, to-

* Corresponding author. Tel.: +358 504636186.

E-mail address: Mariia.Kozlova@lut.fi (M. Kozlova).

ISSN: 2663-6859 print/2663-6867 online

(C) 2020 ISEIS All rights reserved. doi:10.3808/jeil.202000041. gether with simple cash-flow scenario creation, suitable for generating quick and dirty yet intuitively understandable results to support design decisions. The process involves four steps:

i) Policy formulation and parameter value estimation, which includes the design of the policy-mechanism used and the evaluation of the "universal parameters" that surround each policy, such as the determination of capacity factors for the different RE technologies and the investment costs per MW of installed capacity;

ii) Cash-flow scenario generation, that takes place, based on the formulated policies and the parameter values for each policy and each RE technology separately. Typically, three scenarios are generated for each policy-technology combination that reflect the minimum possible, the maximum possible, and the best estimate scenarios;

iii) Pay-off distribution creation takes place, based on the generated cash-flow scenarios, and more precisely based on the net present values (NPV) calculated for the three scenarios for each policy-technology combination. From the pay-off distribution descriptive numbers, such as the real option value for the investment and "success factor" are calculated;

iv) Results presentation and visualization are the butter on the bread that makes the results of the analysis work intuitively understandable to the decision-maker. It is here that the effect of a policy can be made visually understandable at a single glance. Figure 1 depicts the flow of the proposed four process steps. 


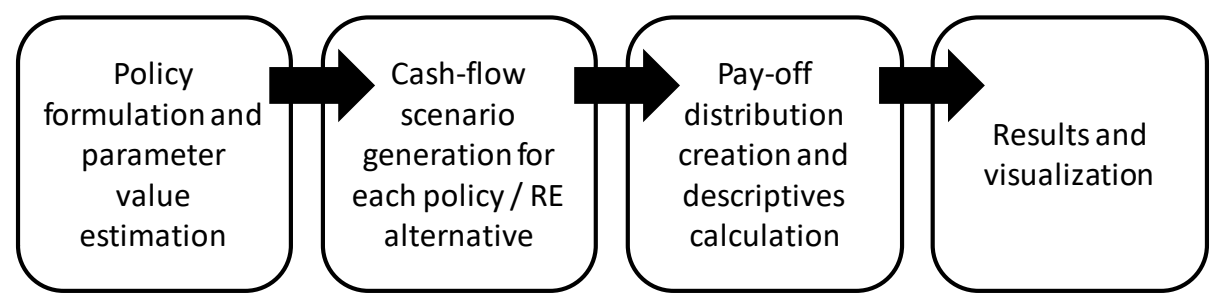

Figure 1. The proposed process for RE policy evaluation.

In order to compare different policies or different auctiondesigns within a policy, one would construct several (the needed amount) of policy models and generate the cash-flow scenarios for each policy-technology alternative. From the NPVs of the scenarios one would then construct pay-off distributions for which one would calculate the needed descriptive numbers and construct numerical comparisons. One would also visualize the results for intuitive visual comparison. For "tuning" the designs one would change design parameters and re-calculate until the desired design outcome is reached.

To illustrate the real-world application of the process, we use a recent case from Finland, one of the countries that has adopted an auction-based RE support system and in this vein, we study the results of a recent RE auction in Finland. The auctions in the Finnish scheme are technology-neutral, meaning that all types of RE projects, with different power generation technologies, compete in a single auction. The latest auction results show that only wind power projects were able to win - the question raised is "why?". We use the proposed procedure to illustrate how the results from the Finnish case can be analyzed and show that the process reveals in a simple and intuitive way the reason for the auction outcome.

The presented results are new and relevant for both RE policy-makers and investors potentially interested in investing in RE generation. Furthermore, they illustrate a novel application area for the fuzzy pay-off method. The paper continues as follows: in the next subsection we present selected research on auction-based RE policies in line with the first part of the process (policy modeling) and then in the following section introduce the fuzzy pay-off method. Application of the process is illustrated with a numerical case-example. Finally, the paper is closed with a short discussion and some conclusions are drawn.

\subsection{On Auction-Based RE Policies}

Auction-based RE support policies include a component of competitive price-bidding process for determining a (guaranteed) floor electricity price premium level for a unit of produced renewable energy that is high enough to allow profitable production. Potential RE producers bid down this premium that determines the size of the possible subsidy depending on the electricity price level. Typically, a public entity (regulator/government) pre-determines the amount of subsidized production (capacity) to be auctioned (see Azuela and Barroso, 2012). The design of the auction-component in the RE policy has a great impact on which projects are ultimately selected to be supported by the policy (are realized). This indicates that if there are specific policy goals, e.g., with regards to the energy production technology mix, such goals should be taken into consideration also in the auction component design. While the competition in the auctions allows, at least in theory, the discovery of a low cost-level of renewable energy and thus helps to minimize the cost of the support mechanism (Winkler et al., 2018) it may also "play-out" technologies that are not most competetive or cause other kinds of "surprises" related to the auctionmechanism. Such surprises may be an unwanted side-effect of auctions and therefore it may make sense to analyze the possible auction outcomes ex-ante to understand what can be expected.

Despite the well-established economic theory and literature around auctions in general (Krishna, 2009), auction-based RE-support mechanisms have not received a lot of attention, at least from the auction-modeling effect on the project profitability point-of-view (Kozlova, 2017). The observed deviations of the reality of RE auctions from the (general or standard) theory of auctions (Haufe and Ehrhart, 2018) may be one of the reasons behind this research gap - the deviations include, e.g., (strongly) imperfect competition, multi-project bidders, transparency of competitors, and the existence of asymmetric beliefs (Haufe and Ehrhart, 2018).

RE auctions have mostly been analyzed in the literature by using case studies, (see Buckman et al., 2019; Welisch, 2019; Lucas et al., 2020). The empirical study by Winkler and others (Winkler et al., 2018) finds that RE auctions are not necessarily as effective and cost-efficient as they are commonly perceived to be. Their study includes five countries that have introduced auction-based systems for RE as a substitute for previous feedin tariff and certificate trading systems (Brazil, France, Netherlands, South Africa, and Italy). They highlight the importance of the auction-design with respect to the goals, the guarantees given, and the penalties involved as factors of the RE promotion success.

\section{Fuzzy Pay-Off Method}

The fuzzy pay-off method is a recently introduced profitability analysis method (Collan et al., 2009; Collan, 2012) that uses the net present value from multiple (typically three) project cash-flow scenarios to create a possibility distribution that more holistically represents the net present value (NPV) of the investment in question. The point is to present the profitability of the investment as a distribution rather than presenting it with a single number. The cash-flow scenarios used (elicited from managers) are a scenario that depicts the best (or the maximum) 
possible profitability outcome, a scenario that depicts the worst (or the minimum) possible profitability outcome, and a scenario that presents the best estimate profitability outcome for the project. The NPVs of these scenarios represent the highest and the lowest possible profitability from the project and the outcome that is most likely to take place and fully belongs to the set of possible outcomes. The minimum and the maximum NPV are used as the extremities of the closed interval of possible outcomes and are, as the extremities assumed to have a limit to zero membership in the set of possible outcomes. The distribution of possible outcomes that is created (the possibility distribution) is hence (assumed to be) a bounded distribution. The best estimate NPV is considered to fully belong to the set of possible alternatives. The fuzzy pay-off method creates the distribution from these three points by assuming a linear relationship between the grade to which the extremities (lim 0 ) and the best estimate (full) belong to the set of possible NPVs and thus in the case of three points (scenario NPVs) the pay-off distribution is a triangle. A triangular possibility distribution can be and is treated for the purposes of further calculations as a fuzzy number (Collan et al., 2009).

Once the (fuzzy) pay-off distribution has been created, descriptive single numbers for the distribution can be calculated based on the information contained in the distribution. The tobe-calculated descriptive numbers may include a centroid (single number representative for the project NPV that the distribution represents) that can be calculated in various ways, measures of variance that can be understood as measures of uncertainty or "risk" associated with using the centroid as a representative of the project NPV, and simple measures of success (measured as how much of the distribution is on the positive NPV side). Furthermore, and importantly, a real option value for the project can be calculated directly from the information contained in the fuzzy pay-off distribution. For details about the derivation of the method and the calculation of descriptive numbers we refer the interested reader to see (Carlsson and Fullér, 2001; Collan et al., 2009; Collan, 2012).

The method and the calculations connected to it are computationally cheap and it can easily be implemented in a spreadsheet environment - the original idea of the method is to be easy-to-use and to implement. The FPOM is able to deal with imprecise information typical to forward looking and human estimation-based evaluations like policy effect analysis. The results from the method are intuitively understandable and easily be visualized. Uncertainty is presented in a way that is similar to the one commonly used in presenting the results of, e.g., Monte Carlo simulation (Kozlova et al., 2016).

The FPOM has also previously been used in the analysis of renewable energy investments (Kozlova et al., 2016) and other applications of the method include, e.g., energy and oil investments (Bednyagin and Gnansounou, 2011; Borges et al., 2018), R\&D project selection (Hassanzadeh et al., 2012; Collan and Luukka, 2014), patent portfolio management (Collan et al., 2013), valuation of large irreversible investments (Collan, 2011). Most of the previous applications have similarities to RE policy alternative analysis and comparison. To the best of our knowledge the method has previously not been used in evaluation of auction-based RE policies. In the following section the application of the above-described process is illustrated with a numerical case.

\section{Case: Analyzing the Finnish RE Auction Results}

In this section the proposed analysis process is applied to the analysis of the results of the first Finnish RE-support system auction. First the Finnish system design is discussed, then the parameter values used are presented and the resulting cashflow scenarios for two RE technologies, wind and solar power, created by using the system design and the parameter values as a basis. The section finally presents the creation of the pay-off distributions for both studied technologies and presents the analysis results.

\subsection{Finnish Auction-Based RE Support Scheme (Step 1, Policy Design)}

The Finnish auction scheme for renewable energy came into force in 2018, following the recommendations of a working committee of the Finnish Ministry of Economic Affairs and Employment. The main benefits of a tendering-based subsidy were stated to be cost efficiency, versatility, and transformability alongside flexibility to quickly respond to a possible increase in energy demand (Working Committee of Development of the Renewable Energy Support System, 2016). The Energy Authority of Finland organized the first technology-neutral auction in the fall of 2018, open for projects of wind, solar, and wave power, as well as project generating electricity from biomass and biogas. However, only wind power projects submitted tenders to the auction (Finnish Energy Authority, 2019). The results of the auction are presented in Table 1, including the accepted projects with the premiums and electricity production data provided in the tenders.

Size of the projects and the premiums they tendered vary greatly. The smallest plant consists of 4 generators, whereas the largest consists of 27 generators. The premiums range between 1.27 $€ / \mathrm{MWh}$ and 3.97 €/MWh. The variation in the premiums is explained with the closed auction, where the projects were accepted in order of cost-efficiency until the combined annual electricity generation would be met. This would open an interesting avenue for discussions about game theoretical analysis about optimal bidding behavior, but it is outside the scope of this paper.

The combined maximum annual electricity generation (capacity) put up for auction was 1.4 TWh (Finnish Energy Authority, 2019) and all the bids had to include information on the premium the projects wish to receive and the annual production of electricity they are offering for that premium (Act 1396/ 2010). The projects must start producing electricity within three years of acceptance, and the support can be received for a maximum of twelve years (ibid.).

The subsidy is calculated for the projects based on the premium the project has stated in its bid, three-month average market electricity price, the reference price for electricity of 30 $€ / \mathrm{MWh}$, and the amount of energy produced during a period of 
Table 1. Projects Accepted in the First Auction (Finnish Energy Authority, 2020)

\begin{tabular}{|c|c|c|c|c|c|c|c|c|}
\hline $\begin{array}{l}\text { The producer of } \\
\text { electricity }\end{array}$ & Power plant & $\begin{array}{l}\text { Type of } \\
\text { plant }\end{array}$ & Region & $\begin{array}{l}\text { Premium } \\
(€ / M W h)\end{array}$ & $\begin{array}{l}\text { First subsidy } \\
\text { period }\end{array}$ & $\begin{array}{l}\text { Yearly } \\
\text { production } \\
(\text { Mwh) } \\
\end{array}$ & $\begin{array}{l}\text { Nominal } \\
\text { capacity } \\
\text { (MVA) } \\
\end{array}$ & $\begin{array}{l}\text { Number of } \\
\text { generators }\end{array}$ \\
\hline Tuuliwatti Oy & $\begin{array}{l}\text { Tuuliwatti Simo } \\
\text { Leipiö III }\end{array}$ & Wind & Lapland & 2.94 & $4 / 2022$ & 370000 & $100-130$ & 27 \\
\hline CPC Finland Oy & Lakiakangas 3 & Wind & Ostrobothnia & 1.89 & $4 / 2022$ & 215000 & $65-165$ & $15-23$ \\
\hline $\begin{array}{l}\text { Kalax Vindkraft } \\
\mathrm{Ab} / \mathrm{Oy}\end{array}$ & Kalax & Wind & Ostrobothnia & 2.87 & $4 / 2022$ & 320000 & $80-126$ & $17-21$ \\
\hline $\begin{array}{l}\text { Kestilän } \\
\text { Kokkonevan } \\
\text { Tuulivoima Oy }\end{array}$ & $\begin{array}{l}\text { Kestilän } \\
\text { Kokkonevan } \\
\text { Tuulivoima }\end{array}$ & Wind & $\begin{array}{l}\text { Northern } \\
\text { Ostrobothnia }\end{array}$ & 1.27 & $1 / 2022$ & 120365 & 32,9 & 7 \\
\hline Puhuri Oy & Hankilanneva & Wind & $\begin{array}{l}\text { Northern } \\
\text { Ostrobothnia }\end{array}$ & 2.62 & $10 / 2021$ & 107000 & $25,2-39,9$ & $6-7$ \\
\hline Puhuri Oy & Parhalahti & Wind & $\begin{array}{l}\text { Northern } \\
\text { Ostrobothnia }\end{array}$ & 1.89 & $4 / 2021$ & 158000 & $42-57$ & $8-10$ \\
\hline $\begin{array}{l}\text { Tuulipuisto Oy } \\
\text { Hirvineva }\end{array}$ & $\begin{array}{l}\text { Hirvineva- } \\
\text { Liminka }\end{array}$ & Wind & $\begin{array}{l}\text { Northern } \\
\text { Ostrobothnia }\end{array}$ & 3.97 & $10 / 2020$ & 70500 & 22 & 4 \\
\hline
\end{tabular}

three months. When market price exceeds the reference price plus premium, no subsidy is paid. If the market price is between the reference price and the reference price plus the premium, the amount of subsidy is calculated as the difference of reference price plus premium and market price. When the threemonth average market price remains equal or under $30 € / \mathrm{MWh}$, the premium is paid in full (Finnish Parliament, 2010).

\subsection{Parameter Value Estimation (Step 1)}

The case concentrates on wind and solar power technology and the parameter values to be estimated revolve around the costs of these technologies and the ability of these technologies to produce energy. Here we use data for Finland from the report by Vakkilainen and Kivistö (2017) and specifically the numbers for capital costs, operational and maintenance costs, and capacity factors are used. The economic life of a wind power plant is assumed to be 25 years and 20 years for solar power respectively. For the purposes of this illustration the electricity price has been projected until 2046 and the revenue that is received by the project is assumed to also include the premium, in accordance with the auction-based policy scheme. The premium used in the analysis is $2.58 € / \mathrm{MWh}$, which is the weighted average of winning bids from the first auction (see Table 1). The nominal capacity of the power plant is assumed to be 20 MW, the discount rate of $6.5 \%$ is used, and the Finnish corporate tax rate of $20 \%$ is applied. The parameter values used are summarized in Table 2. All the other parameter values remain constant, while the electricity price is expected to change.

\subsection{Cash-Flow Scenario Generation (Step 2)}

For the purposes of the analysis three cash-flow scenarios are created by using the parameter values from Table 2 and (simple) assumptions about the electricity price development, where we assume three possible future electricity price scenarios such that the best estimate scenario for the price of electricity is created by using historical yearly data as a basis and by assuming one (average) price point for each year in the future that is used in the estimation of the yearly cash-flows for the investment in the studied two types of RE technology. The depreciation of the investment is assumed to take place as "straight line" in twenty-five years.

The minimum possible and the maximum possible scenario electricity revenue cash-flows are assumed to be 50 and $150 \%$ of the best estimate cash-flow for each year; this is a great simplification. The cash-flow creation and the calculation of the present value of the yearly cash-flows and the scenario net present values for the three scenarios was done by using a commonly used spreadsheet software. The resulting net present values for the three scenarios for both technology types are visible in Table 3.

Table 2. Parameter Values Used in the Analysis

\begin{tabular}{lll}
\hline Variable & Wind & Solar \\
\hline Capital costs $(€ / \mathrm{MW})$ & 1360000 & 1080000 \\
Operating and maintenance costs & 7.7 & 14.85 \\
$(€ / \mathrm{MWh})$ & & \\
Capacity factor & $33.1 \%$ & $11.4 \%$ \\
Nominal capacity of plant $(\mathrm{MW})$ & 20 & 20 \\
Operational lifetime & 25 & 20 \\
Premium $(€ / \mathrm{MWh})$ & 2.58 & 2.58 \\
Discount rate & $6.5 \%$ & $6.5 \%$ \\
\hline
\end{tabular}

Table 3. Net Present Values for the Three Scenarios for both Wind- and Solar Power and the Three Descriptive Numbers for the both Technologies

\begin{tabular}{lll}
\hline & Wind & Solar \\
\hline Maximum NPV & 15.60 & -7.24 \\
Best estimate NPV & 0.58 & -12.42 \\
Minimum NPV & -13.47 & -17.25 \\
Possiblistic mean $(\mathrm{M} €)$ & 0.74 & -12.36 \\
Success ratio & $56 \%$ & $0 \%$ \\
Real option value $(\mathrm{M} €)$ & 1.56 & 0.00 \\
\hline
\end{tabular}




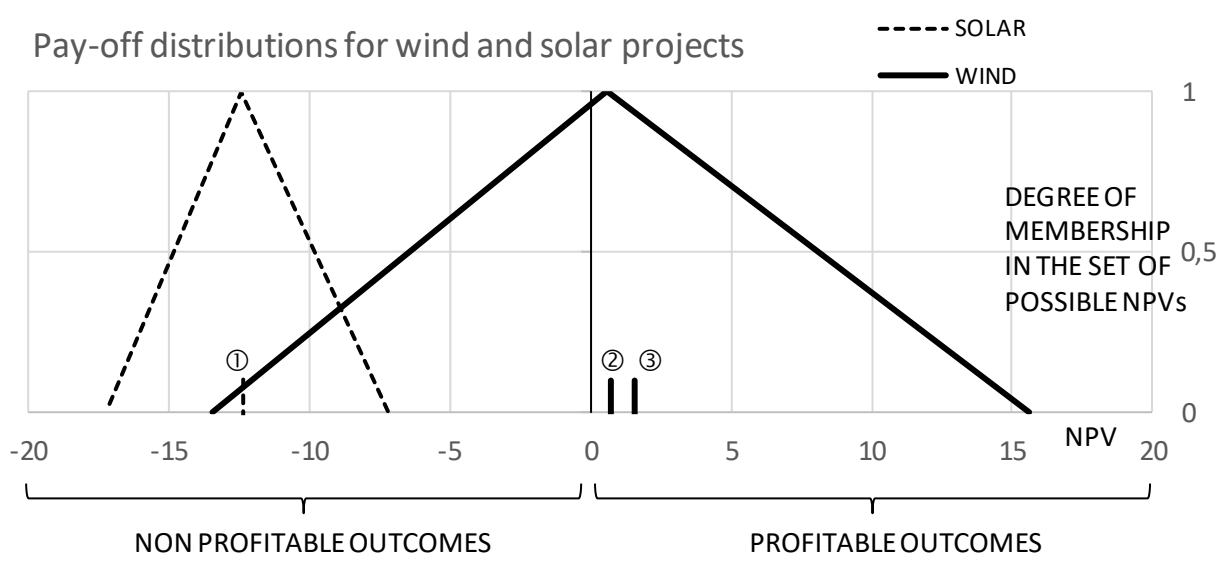

Figure 2. The pay-off distributions for the wind- and solar power investments under the Finnish auction-based RE support mechanism. The clear message is that solar RE is not profitable under the design, while the wind power investments have a positive upside and the profitability if presented with a single number is also positive. Points (1) and (2) represent the possibilistic mean value for solar and wind investments and point (3) the real option value for the wind project. NPV scale in $€$ millions.

\subsection{Pay-Off Distribution Construction and Descriptive Calculation (Step 3)}

Pay-off distributions are constructed for the both studied technologies, based on the net present values calculated for each scenario from the scenario cash-flows. This means that for the profitability of the both technologies a triangular pay-off distribution is constructed that graphically presents the net present value distribution for the both technologies. The procedure used is as described above and we refer the interested reader to see the original paper on the pay-off method and the application oriented book (Collan et al., 2009; Collan, 2012) for more details.

In addition to the pay-off distributions we calculate descriptive numbers for the profitability of both technologies. For the purposes of this illustration we limit the descriptive numbers to three: the possibilistic mean, the success ratio, and the real option value. The possibilistic mean is a centroid that is calculated from the pay-off distribution and is a single number representation of the distribution that takes into consideration the possible asymmetry of the distribution. If the pay-off distribution is symmetric or close to symmetric the possibilistic mean will be close to or coincide with the best estimate scenario net present value (as is the case here), but if the pay-off distribution is very skewed there may be considerable difference between the two. The success ratio is simply the ratio of the area of the pay-off distribution that resides above positive net present values and the whole area of the pay-off distribution that is, a percentage that represents the positive profitability outcomes over all possible outcomes. As the pay-off distribution is a fuzzy number (possibility distribution) the success ratio is not a probability of getting a positive probability outcome from the project, but it is a description that carries similar information in the possibilistic terms. The real option value is a single number that gives out information about the profitability potential of an investment - the number carries information about the size of the "upside" of an investment. For example, if two projects have the same net present value (expected prof- itability) and the other has a higher real option value that indicates higher upside potential, then ceteris paribus, a decisionmaker may want to choose the project with the higher potential for the upside as the expectation of profitability is otherwise the same. This indicates that the real option value is very useful in the comparison of investment alternatives and in the context of this paper, in the comparison of RE policy alternatives.

The three descriptive numbers we calculate give a rather good holistic understanding about the "general expectations", the potential, and the expectations of success (in terms of profitability) of a project. Bundled with the pay-off distribution and graphical presentation they offer good decision-support for understanding the effect that different RE policy designs carry for investors interested in starting generation projects based on different RE technologies.

\subsection{Result Presentation (Step 4)}

Presenting analysis results in a digestible format is a key element in getting the message through and decision-makers can make decisions that correctly reflect their preferences. In the case of pay-off distribution based analysis the graphical presentation of the results is one key advantage over using single numbers, because the pay-off distribution contains information about the imprecision of the analysis results. When the presentation is complemented by presenting the single descriptive numbers, we feel that the process offers rather good decisionsupport in terms of results presentation. Figure 2 shows a graphical presentation of the results, pay-off distributions for both wind and solar power investments based on the Finnish auction-based RE support mechanism.

From Figure 2 it is easy to see that all the expected profitability outcomes for the solar power projects are negative, which means that it would under no circumstances be profitable to start such projects under the present policy design. On the other hand, what can be seen is that there is a considerable "mass" of possible profitable outcomes for the wind energy projects, which makes them possible investments from the in- 
vestor point of view. All the possible outcomes for the solar technology are quite tightly distributed around the best estimate net present value, a sign of "low risk" in terms of how financial risk is typically defined - at the same time the possible profitability outcomes of the wind technology are much more widely spread and correspondingly the variance and hence the risk is higher.

These views about the differing profitability of these technologies is supported by the descriptive numbers visible in Table 3 that show that the success factor for the solar power projects is zero, while for wind it is $56 \%(0.56)$. The size of the potential and the lack thereof is clearly visible from the real option value and the single number representative for the pay-off distribution, the possibilistic mean is negative for solar technology, while it is slightly positive for wind. The descriptive numbers are presented together with the graphical presentation of the pay-off distributions and help in gaining a holistic picture of the profitability of investments into the two technologies under the Finnish RE support mechanism. The reason for wind project success in the auction is clearly visible from Figure 2 wind can be profitable, while solar technology cannot, irrespective of the used electricity price range.

\section{Conclusions}

Support policy designs have an important effect on the profitability outcomes of investments into renewal energy production - production technologies that may otherwise be unprofitable under all electricity market price conditions can made profitable by using support policies. This does not mean, as was illustrated here in the case of an auction-based support mechanism, that all technologies are necessarily made profitable. Furthermore, the reasons for auction outcomes may be understood better, if the effects different support mechanism designs have on project profitability are known ex-ante.

A four-step process for profitability analysis of RE investment projects based on the pay-off method was presented and illustrated with a numerical case from Finland. The proposed process and the pay-off method is easy to use and the results from the analysis can be presented graphically, which makes understanding them relatively easy. In the Finnish auctionbased RE support mechanism context, the results presented show that wind projects can be under favorable electricity price conditions profitable, while solar projects are under all studied circumstances wealth destroying. This explains why the winning bids in the first Finnish technology-neutral RE concession auction did not include any solar energy projects. In fact, all the bids were from wind energy projects. This highlights also the fact that if the participation from a wider range of technologies is wanted (a policy choice), then a technology neutral auction may not function, until a positive profitability can be reached with multiple technologies. Another way is to go the way of technology specific support designs.

It is possible to test different mechanism designs with the proposed method in order to find a suitable method design that corresponds to expectations and policy-maker preferences. The proposed method is easy to use and quite robust, we therefore expect that it suits fast and high-level tuning of models well. The proposed method is relevant to policy designers and to decision-makers both on the regulator/policy-maker side and to investors interested in investing in RE projects.

Acknowledgements. This research was supported in part by funding from the Finnish Strategic Research Council, grant number 313396/ MFG40 - Manufacturing 4.0, and the grant no. 190197 received from the Foundation for Economic Education, Finland.

\section{References}

Azuela, G.E., and Barroso, L.A. (2012). Design and performance of policy instruments to promote the development of renewable energy: Emerging experience in selected developing countries. World Bank Publications.

Bednyagin, D., and Gnansounou, E. (2011). Real options valuation of fusion energy RandD programme. Energy Policy, 39(1), 116-130. https://doi.org/10.1016/j.enpol.2010.09.019

Borges, R.E.P., Dias, M.A.G., Neto, A.D.D., and Meier, A. (2018). Fuzzy pay-off method for real options: The center of gravity approach with application in oilfield abandonment. Fuzzy Sets and Systems, 353, 111-123. https://doi.org/10.1016/j.fss.2018.03.008

Buckman, G., Sibley, J., and Ward, M. (2019). The large-scale feed-in tariff reverse auction scheme in the Australian capital territory 2012, to 2016. Renewable Energy, 132, 176-185. https://doi.org/10.1016/ j.renene.2018.08.011

Carlsson, C., and Fullér, R. (2001). On possibilistic mean value and variance of fuzzy numbers. Fuzzy Sets and Systems, 122(2), 315-326. https://doi.org/10.1016/S0165-0114(00)00043-9

Collan, M. (2012). The pay-off method: Re-inventing investment analysis. CreateSpace Inc., Charleston, NC, USA

Collan, M. (2011). Valuation of industrial giga-investments: Theory and practice. Fuzzy Economic Review, 16(1), 21. https://doi.org/ 10.25102/fer.2011.01.02

Collan, M., Fedrizzi, M., and Luukka, P. (2013). A multi-expert system for ranking patents: An approach based on fuzzy pay-off distributions and a TOPSIS-AHP framework. Expert Systems with Applications, 40(12), 4749-4759. https://doi.org/10.1016/j.eswa.2013.02. 012

Collan, M., and Luukka, P. (2014). Evaluating RandD projects as investments by using an overall ranking from four new fuzzy similarity measure-based TOPSIS variants. Fuzzy Systems, IEEE Transactions On, 22(3), 505-515. https://doi.org/10.1109/TFUZZ. 2013.2260758

Collan, M., Fullér, R., and Mezei, J. (2009). A fuzzy pay-off method for real option valuation. Journal of Applied Mathematics and Decision Sciences, 2009, 1-14. https://doi.org/10.1109/BIFE. 2009.47

Finnish Energy Authority. (2019). Support for seven projects awarded through auction - the average price of accepted tenders EUR 2,5 per MWh. https://energiavirasto.fi/tiedote/-/asset_publisher/uusiutuvan -energian-tarjouskilpailusta-tukea-seitsemalle-hankkeelle-hyvaksyt tyjen-tarjousten-keskihinta-2-5-euroa-mwh?_101_INSTANCE_aR bx5sYgeQOs_languageId=en_US

Finnish Energy Authority. (2020). Preemiojärjestelmä. [premium system]. https://energiavirasto.fi/preemiojarjestelma

Act 1396/2010. Laki uusiutuvilla energialähteillä tuotetun sähkön tuotantotuesta. [Act on production subsidy for electricity produced from renewable energy sources]. https://www.finlex.fi/fi/laki/ajan tasa/2010/20101396

Hassanzadeh, F., Collan, M., and Modarres, M. (2012). A practical approach to RandD portfolio selection using the fuzzy pay-off method. Fuzzy Systems, IEEE Transactions On, 20(4), 615-622. https://doi.org/10.1109/TFUZZ.2011.2180380 
Haufe, M., and Ehrhart, K. (2018). Auctions for renewable energy support-Suitability, design, and first lessons learned. Energy Policy, 121, 217-224. https://doi.org/10.1016/j.enpol.2018.06.027

Murdock, H.E., Adib, R., Lins, C., Guerra, F., Misra, A., Vickery, L., Collier, U., Le Feuvre, P., Bianco, E., Mueller, S., and Philibert, C. (2018). Renewable energy policies in a time of transition. International Renewable Energy Agency (IRENA), OECD/International Energy

Kozlova, M. (2017). Real option valuation in renewable energy literature: Research focus, trends and design. Renewable and Sustainable Energy Reviews, 80, 180-196. https://doi.org/10.1016/j.rser.2017. 05.166

Kozlova, M., Collan, M., and Luukka, P. (2016). Comparison of the datar-mathews method and the fuzzy pay-off method through numerical results. Advances in Decision Sciences, 2016 https://doi. org/10.1155/2016/7836784

Krishna, V. (2009). Auction theory Academic press.

Lucas, H., del Río, P., and Cabeza, L.F. (2020). Stand-alone renewable energy auctions: The case of Peru. Energy for Sustainable Development, 55, 151-160. https://doi.org/10.1016/j.esd.2020.01.009
Murdock, H.E., Gibb, D., André, T., Appavou, F., Brown, A., Epp, B., Kondev, B., McCrone, A., Musolino, E., Ranalder, L., Sawin, J.L. (2019). Renewables 2019 global status report. http://www.ren 21.net/wp-content/uploads/2018/06/17-8652_GSR2018_FullRepor t_web_final_.pdf

Vakkilainen, E., and Kivistö, A. (2017). Sähkön tuotantokustannusvertailu. LUT Scientific and Expertise Publications/Tutkimusraportit-Research Reports

Welisch, M. (2019). Multi-unit renewables auctions for small marketsdesigning the Danish multi-technology auction scheme. Renewable Energy, 131, 372-380. https://doi.org/10.1016/j.renene.2018.07.044

Winkler, J., Magosch, M., and Ragwitz, M. (2018). Effectiveness and efficiency of auctions for supporting renewable electricity-What can we learn from recent experiences? Renewable Energy, 119, 473-489. https://doi.org/10.1016/j.renene.2017.09.071

Working Committee of Development of the Renewable Energy Support System. (2016). The final report of the working committee of development of the renewable energy support system. Ministry of economic affairs and employment publications. http://urn.fi/ URN: ISBN: 978-952-327-111-1 